\title{
Technology and Child Development: Evidence from the One Laptop per Child Program
}

Julian Cristia, Pablo Ibarrarán, Santiago Cueto, Ana Santiago And Eugenio SeVerín

\author{
ONLINE APPENDIX
}

FIGURE A1-DISTRIBUTION OF LAPTOP USE BY DAY AND TIME PERIOD

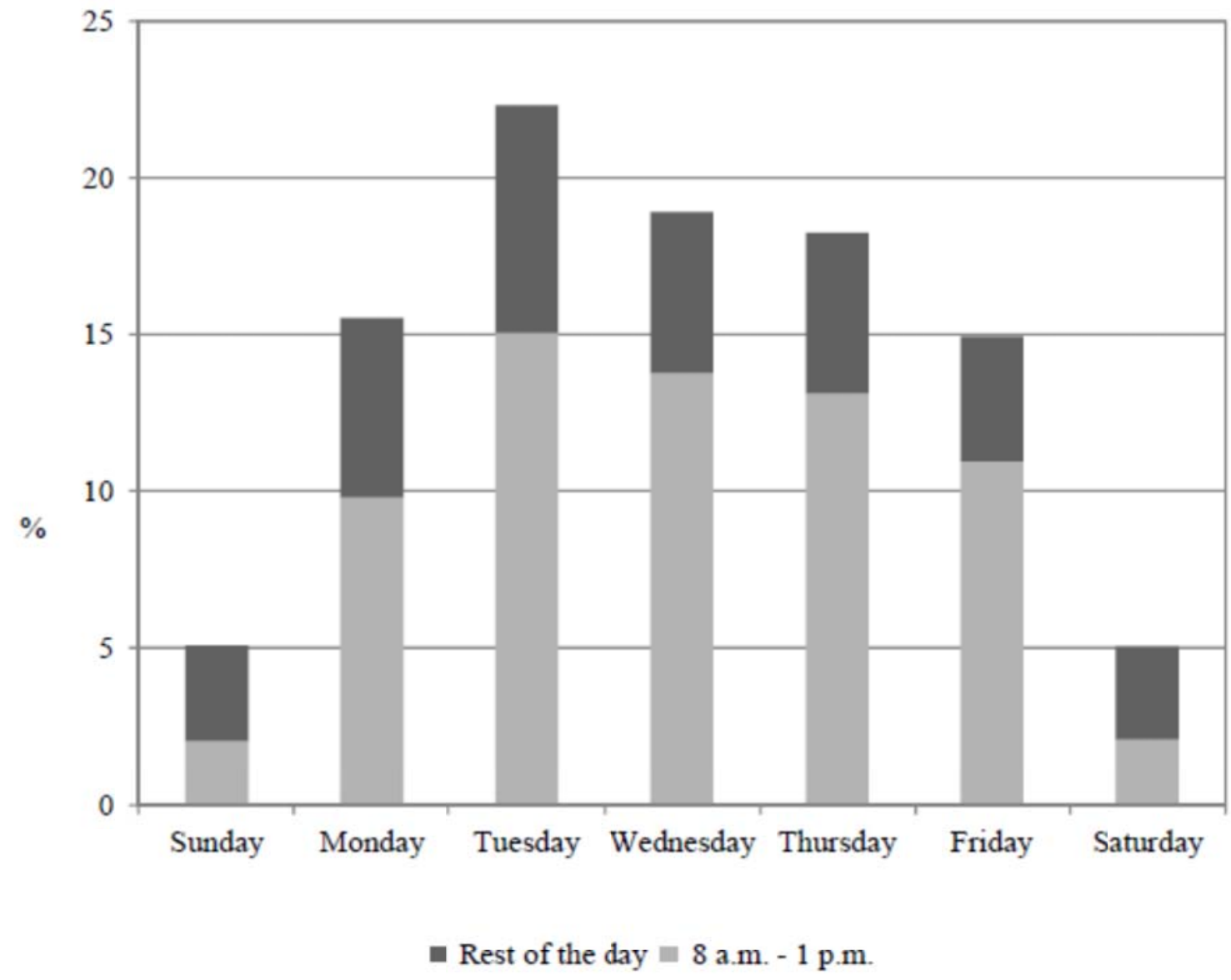

Notes: The sample includes treated students in second grade, followed cohort and sixth grade. Statistics are computed based on logs extracted from the laptops. Percent of use in a day-time period corresponds to the proportion of opened applications at that period averaged across students. Results are generated using the last four laptop sessions. The 8 a.m. to 1 p.m. period matches the regular school schedule. 


\begin{tabular}{lcc}
\hline \hline & All & $\begin{array}{c}\text { Interviewed } \\
\text { sample } \\
(2)\end{array}$ \\
\hline Computer access and use & $(1)$ & \\
Computer access & - & 2.710 \\
Computer use & - & $(0.093)$ \\
& & 0.914 \\
Behavior and noncognitive outcomes & & $(0.064)$ \\
Learning behaviors & - & -0.017 \\
Noncognitive outcomes & - & $(0.040)$ \\
& & -0.116 \\
Academic achievement and cognitive skills & & $(0.056)$ \\
Academic achievement & 0.011 & 0.053 \\
Cognitive skills & $(0.053)$ & $(0.056)$ \\
Academic achievement and cognitive skills & 0.103 & 0.094 \\
& $(0.058)$ & $(0.061)$ \\
& 0.065 & 0.075 \\
Number of students & $(0.049)$ & $(0.050)$ \\
\hline \hline
\end{tabular}

Notes: This table presents estimated differences between the treatment and control groups at the student level for different sub-samples. Each cell in the table corresponds to one regression. Regressions include an indicator for treatment and strata fixed-effects. Results reported in column (1) corresponds to the all sample that includes students in second grade, the followed cohort and sixth grade. Results reported in column (2) corresponds to the interviewed sample that includes students in the followed cohort and sixth grade. Labels in rows correspond to dependent variables. The variables included in the construction of the different summary measures are described in the notes of tables 6, 8 and 9. The table reports the number of students that were tested in Math and Language. Standard errors, reported in parentheses, are clustered at the school level. 
TABLE A2-EFFECTS ON ACADEMIC ACHIEVEMENT AND COGNITIVE SKILLS ROBUSTNESS CHECKS

\begin{tabular}{|c|c|c|c|}
\hline & \multicolumn{2}{|c|}{ All schools } & \multirow{2}{*}{$\begin{array}{l}\text { School where tests } \\
\text { where timed } \\
\text { correctly } \\
\text { (3) }\end{array}$} \\
\hline & (1) & (2) & \\
\hline \multicolumn{4}{|l|}{ Academic achievement } \\
\hline Math & $\begin{array}{c}0.052 \\
(0.060)\end{array}$ & $\begin{array}{c}0.053 \\
(0.060)\end{array}$ & $\begin{array}{c}0.052 \\
(0.080)\end{array}$ \\
\hline Language & $\begin{array}{l}-0.029 \\
(0.055)\end{array}$ & $\begin{array}{l}-0.028 \\
(0.054)\end{array}$ & $\begin{array}{c}0.020 \\
(0.073)\end{array}$ \\
\hline Academic achievement summary measure & $\begin{array}{c}0.011 \\
(0.053)\end{array}$ & $\begin{array}{c}0.012 \\
(0.053)\end{array}$ & $\begin{array}{c}0.034 \\
(0.071)\end{array}$ \\
\hline \multicolumn{4}{|l|}{ Cognitive skills } \\
\hline Raven's Progressive Matrices & $\begin{array}{c}0.106 \\
(0.055)\end{array}$ & $\begin{array}{c}0.105 \\
(0.055)\end{array}$ & $\begin{array}{c}0.140 \\
(0.066)\end{array}$ \\
\hline Verbal fluency test & $\begin{array}{c}0.127 \\
(0.088)\end{array}$ & $\begin{array}{c}0.130 \\
(0.087)\end{array}$ & $\begin{array}{c}0.222 \\
(0.103)\end{array}$ \\
\hline Coding test & $\begin{array}{c}0.078 \\
(0.095)\end{array}$ & $\begin{array}{c}0.084 \\
(0.092)\end{array}$ & $\begin{array}{c}0.230 \\
(0.093)\end{array}$ \\
\hline Cognitive skills summary measure & $\begin{array}{c}0.103 \\
(0.058)\end{array}$ & $\begin{array}{c}0.106 \\
(0.057)\end{array}$ & $\begin{array}{c}0.197 \\
(0.065)\end{array}$ \\
\hline \multicolumn{4}{|l|}{ Academic achievement and cognitive skills } \\
\hline Summary measure & $\begin{array}{c}0.065 \\
(0.049)\end{array}$ & $\begin{array}{c}0.067 \\
(0.048)\end{array}$ & $\begin{array}{c}0.130 \\
(0.060)\end{array}$ \\
\hline Number of students & 4,091 & 4,091 & 2,468 \\
\hline Tests timed correctly indicator & $\mathrm{N}$ & $\mathrm{Y}$ & $\mathrm{N}$ \\
\hline
\end{tabular}

Notes: This table presents estimated differences between the treatment and control groups at the student level. 60.2 percent of students attended schools where the Coding test and the verbal fluency test were applied following the protocol of giving students three minutes to complete the assignment. The tests timed correctly indicator equals 1 for these students. The rest of students were given more time (typically 10 minutes) to finish these tests. Each cell in the table corresponds to one regression. Labels in rows correspond to dependent variables. Regressions in columns (1) to (2) include all students. Regressions in column (3) include students in schools where the mentioned tests were timed correctly. All regressions include strata fixed effects and estimates in (2) are obtained including the test timed correctly indicator. The table reports the number of students that were tested in Math and Language. All tests have been normalized subtracting the mean and dividing by the standard deviation of the control group. The academic achievement summary measure is constructed averaging standardized scores in Math and Language. The cognitive skills summary measures is constructed averaging standardized scores in the Raven's Progressive Matrices, verbal fluency test and Coding test. The academic and cognitive skills summary measure is constructed averaging standardized scores in Math, Language, Raven's Progressive Matrices, verbal fluency test and Coding test. Standard errors, reported in parentheses, are clustered at the school level. 
TABLE A3-LAPTOP USE AND COMPETENCE BY SELECTED SUBGROUPS

TREATMENT GROUP

\begin{tabular}{|c|c|c|c|c|c|c|c|}
\hline & $\begin{array}{l}\text { Second } \\
\text { grade } \\
(1)\end{array}$ & $\begin{array}{c}\text { Followed } \\
\text { cohort } \\
(2)\end{array}$ & $\begin{array}{l}\text { Sixth } \\
\text { grade } \\
\text { (3) }\end{array}$ & $\begin{array}{c}\text { Female } \\
\text { (4) }\end{array}$ & $\begin{array}{l}\text { Male } \\
\text { (5) }\end{array}$ & $\begin{array}{c}\text { Low } \\
\text { baseline } \\
\text { score } \\
(6)\end{array}$ & $\begin{array}{c}\text { High } \\
\text { baseline } \\
\text { score } \\
\text { (7) }\end{array}$ \\
\hline \multicolumn{8}{|c|}{ Panel A: Laptop use (all students with logs extracted) } \\
\hline \multicolumn{8}{|c|}{ Distribution by sessions in last week } \\
\hline None & $0.238^{* *}$ & 0.127 & 0.115 & 0.149 & 0.168 & 0.154 & 0.162 \\
\hline One & $0.192 * *$ & 0.149 & 0.124 & 0.161 & 0.147 & 0.169 & $0.140^{*}$ \\
\hline Two & 0.116 & 0.095 & $0.124 *$ & 0.111 & 0.113 & 0.108 & 0.115 \\
\hline Three & 0.111 & 0.119 & $0.089 *$ & 0.101 & 0.111 & 0.092 & $0.119 *$ \\
\hline Four or more & $0.343^{* *}$ & 0.510 & 0.549 & 0.478 & 0.462 & 0.476 & 0.464 \\
\hline \multicolumn{8}{|l|}{ Distribution by place } \\
\hline School & 0.642 & 0.608 & 0.630 & 0.609 & $0.644 *$ & 0.642 & $0.612^{*}$ \\
\hline Home & 0.358 & 0.392 & 0.370 & 0.391 & $0.356^{*}$ & 0.358 & $0.388 *$ \\
\hline \multicolumn{8}{|c|}{ Distribution by type of application } \\
\hline Standard & $0.435^{* *}$ & 0.478 & 0.499 & 0.502 & $0.441^{* *}$ & 0.484 & $0.460^{*}$ \\
\hline Games & $0.215^{* *}$ & 0.174 & $0.126^{* *}$ & 0.170 & 0.170 & 0.172 & 0.169 \\
\hline Music & 0.101 & 0.108 & $0.133^{* *}$ & 0.093 & $0.136^{* *}$ & 0.111 & 0.118 \\
\hline Programming & 0.054 & 0.063 & 0.053 & 0.052 & $0.062^{*}$ & 0.055 & 0.058 \\
\hline Other & $0.196 *$ & 0.177 & 0.189 & 0.184 & 0.191 & 0.178 & $0.195^{*}$ \\
\hline Number of students & 630 & 645 & 687 & 967 & 995 & 945 & 1,017 \\
\hline \multicolumn{8}{|c|}{ Panel B: Laptop competence (interviewed sample) } \\
\hline \multicolumn{8}{|c|}{ Competences (correct responses average) } \\
\hline Basic operation & & 0.781 & $0.838^{* *}$ & 0.795 & $0.825^{* *}$ & 0.812 & 0.809 \\
\hline Write application & & 0.495 & $0.647 * *$ & 0.555 & $0.588^{* *}$ & 0.565 & 0.578 \\
\hline Wikipedia application & & 0.592 & $0.745^{* *}$ & 0.657 & 0.681 & 0.648 & $0.690 * *$ \\
\hline Picture books & & 0.542 & $0.663^{* *}$ & 0.587 & $0.620^{* *}$ & 0.605 & 0.602 \\
\hline Stories & & 0.559 & $0.705^{* *}$ & 0.622 & 0.644 & 0.628 & 0.637 \\
\hline Journal application & & 0.727 & $0.846^{* *}$ & 0.768 & $0.806^{* *}$ & 0.786 & 0.788 \\
\hline Average competence & & 0.593 & $0.721^{* *}$ & 0.643 & $0.672 * *$ & 0.653 & 0.662 \\
\hline Number of students & & 839 & 862 & 838 & 863 & 817 & 884 \\
\hline
\end{tabular}

Notes: This table presents statistics on patterns of use and laptop competence by groups. It also indicates the statistical significance of differences across subgroups within dimensions analyzed. ** and $*$ denote differences at the five and ten percent level, respectively. For the three analyzed dimensions the comparison groups are: followed cohort, females and schools with average baseline academic achievement below the median. Applications where grouped in five types: Standard (includes write, browser, paint, calculator and chat), Games, Music, Programming and Others. Percent of use by type refer to the proportion of opened applications by group in the last four sessions averaged across students. Percent of use at school is computed in a similar fashion but reporting the proportion of applications that were opened on weekdays from 8 a.m. to $1 \mathrm{p} . \mathrm{m}$. The basic operation subscale measures the competence of the student in turning on/off the laptop, finding certain icons and going back to the home page. In the write application subscale these skills are evaluated: how to make a text bold, underline it, insert tables and save the document. The questions related to the Wikipedia, Picture books, Stories and Journal subscales check whether the student knows how to open/stop each application and her ability to find information about a particular research topic. 